\title{
PRODUCTION OF BIOGAS FROM PALM OIL MILL EFFLUENT: FROM LABORATORY SCALE TO PILOT SCALE
}

\author{
Irvan $^{1,2, *}$, B. Trisakti ${ }^{1,2}$, S. Maulina ${ }^{1,2}$ and H. Daimon ${ }^{3}$ \\ ${ }^{1}$ Chemical Engineering Department, Universitas Sumatera Utara, Medan, 20155, Indonesia \\ ${ }^{2}$ Sustainable Energy and Biomaterial Center of Excellence, Universitas Sumatera Utara, \\ Medan, 20155, Indonesia \\ ${ }^{3}$ Department of Environmental and Life Sciences, Toyohashi University of Technology, \\ Toyohashi, 441-8580, Japan \\ *E-mail: irvan@usu.ac.id
}

\begin{abstract}
An anaerobic closed system using a pilot-scale digester tank has been developed in recent years at Universit as Sumatera Utara. The system was built for the purpose of producing biogas from the fermentation process of palm oil industry effluent obtained from a wastewater treatment plant of the palm oil mills owned by Sisirau Mill. The digester tank used was a reactor with the type of continuous stirred tank reactor has a volume of 3,000 liters equipped with electrical heaters, insulators, and baffles in it. Feed input was performed intermittently so that the operation occurred continuously. In this research, a series of experiments at pilot scale were conducted with 616 liters palm oil mill effluent/day feed rate, the temperature of feed tank $70^{\circ} \mathrm{C}$, digester tank temperature of $55^{\circ} \mathrm{C}$, stirring rate of $37.5 \mathrm{rpm}$, and six days of hydraulic retention time. The results were compared to the results of laboratory scale, under the same condition and same POME. Based on the results, fermentation process at laboratory scale showed the better performance than at pilot scale. Therefore, the process should be improved in order to be scaled up to the higher scale.
\end{abstract}

Keywords: Palm oil mill effluent, biogas, anaerobic, fermentation, thermophilic, pilot scale.

@ RASĀYAN. All rights reserved

\section{INTRODUCTION}

Nowadays, there are many latest environmental problems on our planet, such as, increasing energy consumption, environmental pollution, climate change, burning forest, and others, which are related to the waste production by several anthropogenic activities. Palm oil industry is one of the activities that contribute those problems ${ }^{1,2}$. The Republic of Indonesia is currently considered as the world's largest producer of crude palm oil (CPO) in the world with an area of oil palm plantations in 2015 estimated at 11.3 million hectares $^{3}$. The amount of CPO production is also followed by the large production of palm oil mill effluent (POME). Production of POME is estimated \pm 30 million tons/year. Most palm oil mills still process POME by using open lagoon system before discharge to the environment. This system requires a large area, generates odor, and also releases greenhouse gases ${ }^{4-6}$. Irvan et al., (2010) has successfully converted POME into biogas with the help of anaerobic microbes using a 2-liter continuous stirred tank reactor (CSTR) with a temperature of $55^{\circ} \mathrm{C}$ (thermophilic), closed system, and intermittent feed input. In their research, they succeeded in reducing hydraulic retention time (HRT) to HRT 6 days. This reduction in HRT will reduce the capacity of the digester tank and will also reduce the investment for the implementation ${ }^{7}$.

In order to build and to operate biogas plants at commercial scale, capacity approximately $350 \mathrm{~m}^{3}$ $\mathrm{POME} /$ day for mill capacity of 30-ton $\mathrm{FFB} / \mathrm{hr}^{8}$, this work must pass through several stages of scale-up, from the laboratory/bench scale, pilot scale, demonstration plant and commercial plant. Many parameters need to be addressed in the pilot plant before the demonstration and commercial of biogas plant are constructed especially its digester performance ${ }^{9}$. So in this research, we compare and evaluate the digester performance of laboratory scale and pilot scale, especially the stability of the process, before we step to 
the next scale. This paper reports the conversion of POME to biogas, either at laboratory scale or pilot scale. It describes the performance of the two different systems under the same conditions and same POME.

\section{Palm Oil Mill Effluent}

\section{EXPERIMENTAL}

As the raw material for the experimental anaerobic digestion observed, a real POME obtained from Sisirau Mill wastewater treatment facilities were used. The main properties of this mill effluent are summarized in Table-1.

Table-1: Properties of POME from Sisirau Mill

\begin{tabular}{l|c|c}
\hline \multicolumn{1}{c}{ Parameter } & Unit & Values \\
\hline Total solid & $\mathrm{mg} / \mathrm{L}$ & 64,700 \\
\hline Volatile solid & $\mathrm{mg} / \mathrm{L}$ & 53,900 \\
\hline Suspended solid & $\mathrm{mg} / \mathrm{L}$ & 34,400 \\
\hline BOD & $\mathrm{mg} / \mathrm{L}$ & 59,000 \\
\hline CODcr & $\mathrm{mg} / \mathrm{L}$ & 99,000 \\
\hline TOD & $\mathrm{mg} / \mathrm{L}$ & 75,240 \\
\hline Kj-N & $\mathrm{mg} / \mathrm{L}$ & 1,200 \\
\hline NH & $\mathrm{N}$ & 83 \\
\hline Oil and grease & $\mathrm{mg} / \mathrm{L}$ & 9,200 \\
\hline $\mathrm{C}$ & $\mathrm{mg} / \mathrm{L}$ & 46.2 \\
\hline $\mathrm{H}$ & $\mathrm{wt} \%$ & 6.42 \\
\hline $\mathrm{N}$ & $\mathrm{wt} \%$ & 2.16 \\
\hline $\mathrm{S}$ & $\mathrm{wt} \%$ & 0.43 \\
\hline $\mathrm{P}$ & $\mathrm{wt} \%$ & - \\
\hline COD $: \mathrm{N}: \mathrm{P}$ & - & $350: 4.2: 0.9$ \\
\hline Carbohydrate & wt $\%$ & 58.3 \\
\hline Glucide & wt $\%$ & 47.6 \\
\hline Cellulose & wt $\%$ & 6.2 \\
\hline Hemicellulose & wt $\%$ & 0.0 \\
\hline Lignin & wt $\%$ & 4.5 \\
\hline Protein & wt $\%$ & 10.8 \\
\hline Lipid & wt $\%$ & 14.2 \\
\hline
\end{tabular}

Supported chemicals used were $\mathrm{NaHCO}_{3}$ and trace metals $\left(\mathrm{FeCl}_{2}, \mathrm{Ni} 6 \mathrm{H}_{2} \mathrm{O}\right.$ and $\left.\mathrm{CoCl}_{2} \cdot 6 \mathrm{H}_{2} \mathrm{O}\right)$. The purpose of adding $\mathrm{NaHCO}_{3}$ was to maintain digester $\mathrm{pH}$ of 6.8-7.2 and $\mathrm{M}$-alkalinity content of $\geq 3.000$ $\mathrm{mg} / \mathrm{l}$, while the purpose of addition of $\mathrm{FeCl}_{2}, \mathrm{Ni} .6 \mathrm{H}_{2} \mathrm{O}$, and $\mathrm{CoCl}_{2} \cdot 6 \mathrm{H}_{2} \mathrm{O}$ is to minimize $\mathrm{H}_{2} \mathrm{~S}$ production and for anaerobic microbe metabolism.

\section{Laboratory Scale of Anaerobic Treatment of POME}

The laboratory scale experiment was conducted in Ecology Laboratory, Universitas Sumatera Utara. The anaerobic fermentation process occurred in a 2-liter-capacity glass jar digester (Type MBF 300ME, EYELA) which is provided with temperature-controller-jacket, valves for sampling, discharge, and feeding, also 3 level turbine agitator as well as alarm indicator bulb anticipating temperature chaos. A data logger (Type NR-250, KEYENCE) is connected to a notebook to allow automatic recording of $\mathrm{pH}$ and temperature provided by sensing device attached to the digester. The 2-liter digester for experimental POME fermentation is shown in Fig.-1.

\section{Pilot Scale of Anaerobic Treatment of POME}

The pilot scale plant was located at a Centre of Community Service of Universitas Sumatera Utara. Fig.-2 shows the flow sheet of the pilot plant, while, the technical data of the pilot plant components is on Table-2. The pilot plant consists of main equipment such as: the mixture tank, biogas digester, gas 
RASĀYAN J. Chem.

Vol. 11 | No. 1 | 378 - 385 | January - March | 2018

storage, compressor, and biogas generator set. The experiments were carried out on a biogas power plant schematically presented in Fig.-2. There are two main units include in this process, namely the biogas production unit and the power plant unit. A biogas production unit is a unit that converts POME to biogas. Meanwhile, the power plant unit is a unit that converts biogas into electricity.

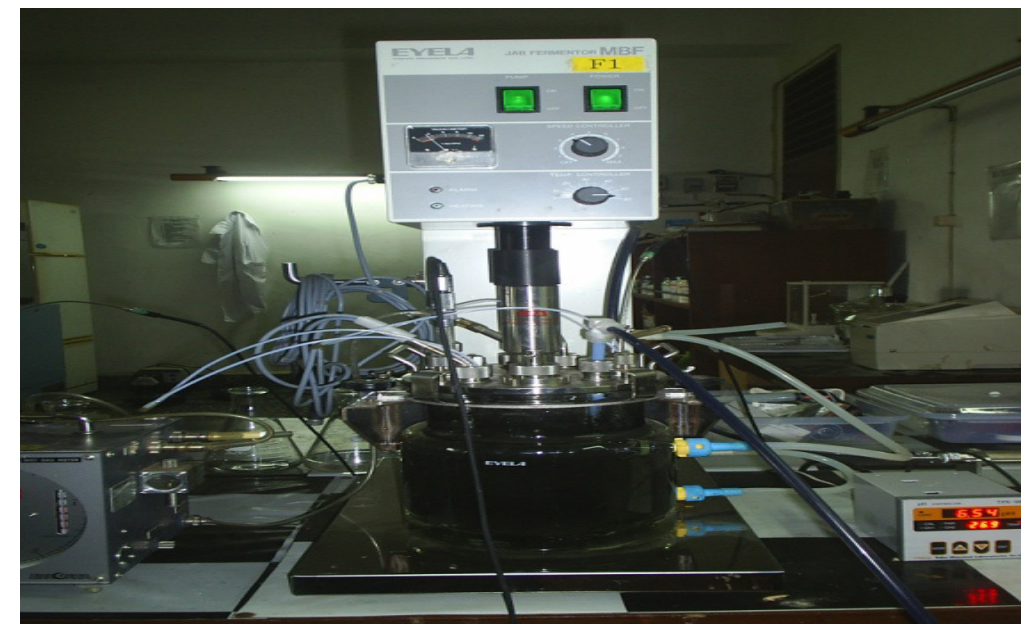

Fig.-1: A two-liter digester used for POME fermentation

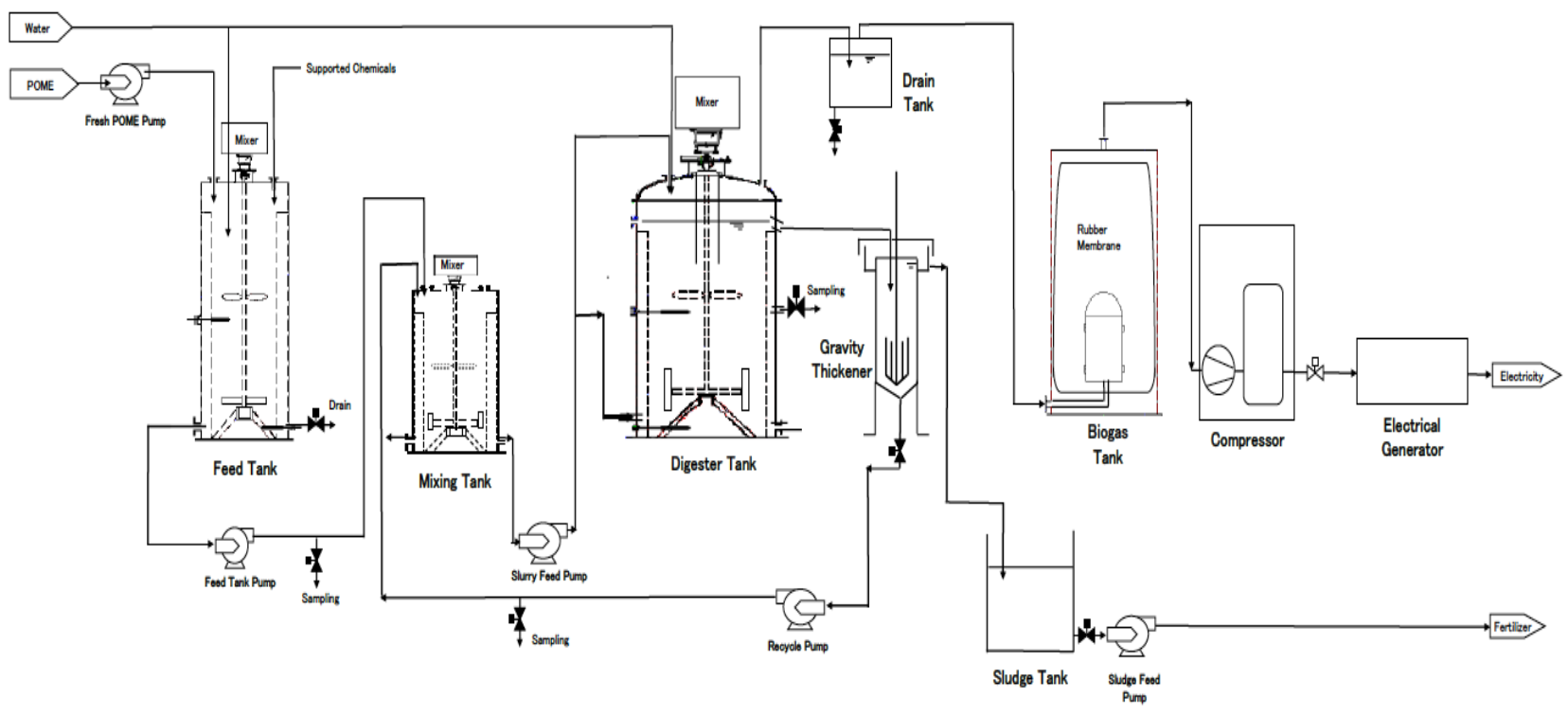

Fig.-2: Flowsheet of Biogas Fermentation at Pilot Scale

Table-2: The Technical Data of the Pilot Plant Components

\begin{tabular}{l|l|l|l}
\hline No. & Components & Specification & Accessories \\
\hline 1. & Mixture tank & $\begin{array}{l}\text { Volume: } 1000 \mathrm{~L} \\
\text { Motor: } 1400 \mathrm{rpm} \\
\text { Power: } 1 \mathrm{HP} \\
\text { Gear box ratio }=1: 60\end{array}$ & $\begin{array}{l}\text { Baffle, level controller, } \\
\text { manhole, sampling hole }\end{array}$ \\
\hline 2. & Pump & $\begin{array}{l}\text { Type: centrifugal } \\
\text { Power: } 1 \mathrm{HP}\end{array}$ & Ball valve, check valve \\
\hline 3. & Digester tank & Volume: $3000 \mathrm{~L}$ & Manhole, sampling \\
\hline
\end{tabular}


RASĀYAN $J$. Chem.

Vol. 11 | No. 1 |378 - 385 | January - March | 2018

\begin{tabular}{l|l|l|l}
\hline & & $\begin{array}{l}\text { Motor: } 1400 \mathrm{rpm} \\
\text { Power: } 3 \mathrm{HP} \\
\text { Gear box: ratio 1: } 60 \\
\text { Heater: } 3 \mathrm{~kW}\end{array}$ & hole, insulator, \\
\hline 4. & Biogas tank & Volume: $2000 \mathrm{~L}$ & Manhole, water trap \\
\hline 5. & Compressor & $\begin{array}{l}\text { Type: Reciprocating } \\
\text { Power: } 1 \text { HP }\end{array}$ & \\
\hline 6. & Generator set & $\begin{array}{l}\text { Machine: combustion engine } \\
\text { Cylinder: } 1600 \text { cc } \\
\text { Combustion: carburetor } \\
\text { Dynamo: } 12 \mathrm{~kW}\end{array}$ & Water cooling system \\
& & & \\
\hline
\end{tabular}

The biogas production unit consists of several main tools: 1,000 liters of feed tank, 3,700 liters of digester tank, 160 liters of mixer tank, 260 liters of gravity thickener, biogas catcher tank equipped with 2,800 liters rubber balloon, a compressor and high-pressure biogas tank. The power plant was equipped by the combustion engine and electrical generator. Originally, the engine was a gasoline-fueled engine then modified to the biogas-fueled engine, while the electrical generator was a 3-phase motor with a capacity of $12 \mathrm{~kW}$. Produced gases were then flown into the water trap to collect the unexpected water in the biogas. The flow of the produced biogas was measured by using the gas meter. Biogas was sucked by compressor then flown to the generator set to generate the electricity. Biogas generation was measured by using a wet gas meter (Type W-NK-0.5B, SHINAGAWA). The content of $\mathrm{H}_{2} \mathrm{~S}$ and $\mathrm{CO}_{2}$ in the produced biogas were analyzed by using a detector tube pump (Type GV-100S, GASTEC) and quick-measuring detector tubes $(25 \sim 1600 \mathrm{ppm}$, GASTEC). Biogas characteristics produced from the fermentation of POME at pilot scale are presented in Table-3.

Table-3: Characteristics of Biogas Production at Pilot Scale

\begin{tabular}{l|c}
\hline Parameter & Values \\
\hline Biogas Production (NL/gr VS) & 0.7 \\
\hline $\mathrm{CH}_{4}(\%)$ & 60 \\
\hline $\mathrm{CO}_{2}(\%)$ & 30 \\
\hline $\mathrm{H}_{2} \mathrm{~S}(\mathrm{ppm})$ & 40 \\
\hline
\end{tabular}

\section{RESULTS AND DISCUSSION}

Comparison of Biogas Generation in Fermentation Process between Laboratory Scale and Pilot Scale

Biogas generation in the anaerobic fermentation process at laboratory scale needs to be compared with pilot plant scale to see their digester performance especially the stability of the process. For this purpose experiment with POME fermentation on laboratory scale was carried out with $333.3 \mathrm{ml} /$ day feed rate, digester temperature of $55^{\circ} \mathrm{C}$ and HRT target 6 days, while fermentation at pilot scale was performed with $616 \mathrm{~L} /$ day feed rate, feed temperature at $70^{\circ} \mathrm{C}$, digester temperature at $55^{\circ} \mathrm{C}$, stirring rate $37.5 \mathrm{rpm}$, and HRT target six days. The biogas production rate per mg degraded VS for POME fermentation both at laboratory scale and pilot scale are presented in Fig.-3.

During the observation, it was obtained that the production rate of biogas fluctuated, where at the beginning of fermentation, gas began to increase but at the end, the gas progressively decreased, it occurred both for laboratory scale and pilot scale. Gas generation on a laboratory scale is more stable than on a pilot scale, this is probably related to the scale of the experiment. Many parameters on the pilot scale are more difficult to maintain such as heating, stirring, and $\mathrm{pH}$ setting. The heating of $3 \mathrm{~m}^{3}$ digester used only 3 units of $1.5 \mathrm{~kW}$ electrical heating elements. It took a long time to reach the digester target temperature of $55^{\circ} \mathrm{C}$. Stirring is also a very important thing, because less effective stirring will cause a scum that can reduce digester performance. Furthermore, small leaks between the weld and flange joints on the equipment are very difficult to detect. 
RASĀYAN J. Chem.

Vol. 11 | No. 1 |378- 385 | January - March | 2018

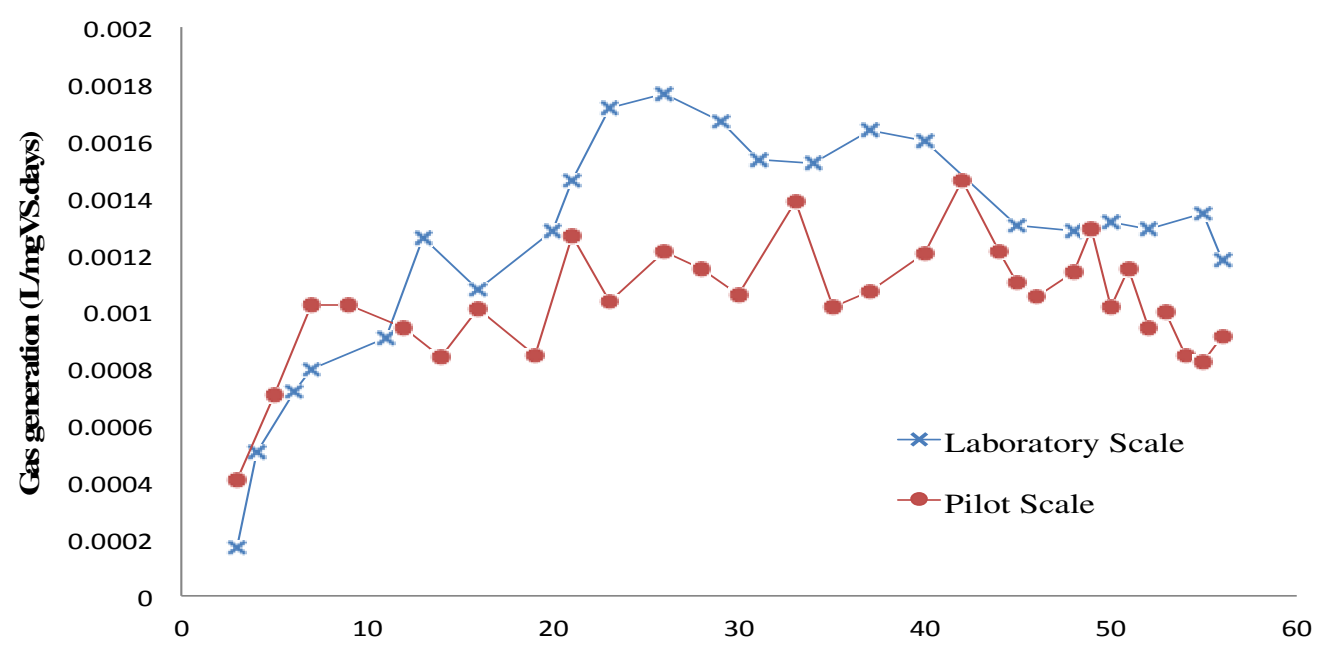

Fermentation Time (day)

Fig.-3: The Comparison of Biogas Production at Laboratory Scale and Pilot Scale

\section{Changes in M-alkalinity and pH at Laboratory Scale and Pilot Scale}

Generally, the concentration of hydrogen ion and M-alkalinity play an important role in the biological processes ${ }^{10}$. Changes in $\mathrm{M}$-alkalinity and $\mathrm{pH}$ during the anaerobic fermentation process at laboratory scale need to be compared with at pilot scale as shown in Fig. -4 and 5.

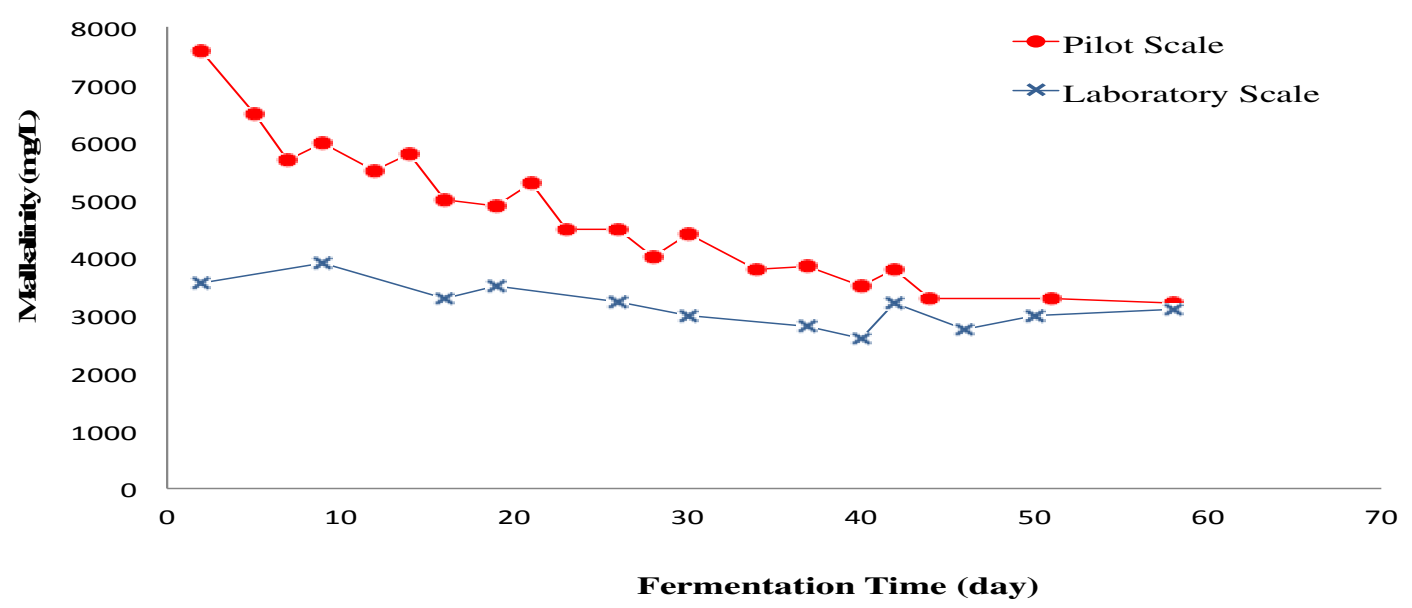

Fig.-4: M-Alkalinity Profiles

For POME fermentation at the laboratory scale, the alkalinity of the digester was lower than that of the digester at pilot scale as seen in Fig.-4. A similar trend also is shown for $\mathrm{pH}$ profile on Figure-5, where the $\mathrm{pH}$ of the digester was lower than that of the digester at pilot scale. In addition, profiles of alkalinity and $\mathrm{pH}$ at laboratory scale more stable than that at pilot scale. This related to the scale of the experiment. In the anaerobic fermentation process, methanogenic bacteria require $\mathrm{pH}$ conditions in the range 6.5 to $7.5^{11}$. To keep this $\mathrm{pH}$ in the range of appropriate conditions required by microorganisms to live, the alkalinity is adjusted by the addition of carbonates. This research used sodium bicarbonate $\left(\mathrm{NaHCO}_{3}\right)$ to 
RASĀYAN J. Chem.

Vol. 11 | No. 1 |378 - 385 | January - March | 2018

adjust the $\mathrm{pH}$ within the appropriate range for anaerobic microbial growth ${ }^{12-16}$. During the loading up 2.5 gram of sodium carbonate per liter of POME was added into the feed tank, then it required around 5 gram for laboratory scale while for pilot plant required $2.5 \mathrm{~kg}$. Then it was easier to mix 5 gram of $\mathrm{NaHCO}_{3}$ in the digester of laboratory scale and make the profiles more stable than at pilot scale. Although at the beginning of the process the alkalinity and $\mathrm{pH}$ values of the pilot scale began at a high value of 8,100 $\mathrm{mg} / \mathrm{L}$ and 8.42 , but gradually decline steadily in the range of values suitable for the anaerobic process, which for alkalinity in the range of 2,000 to $4,000 \mathrm{mg} / \mathrm{L}$ while for $\mathrm{pH} 6.5$ to $7.5^{17,18}$.

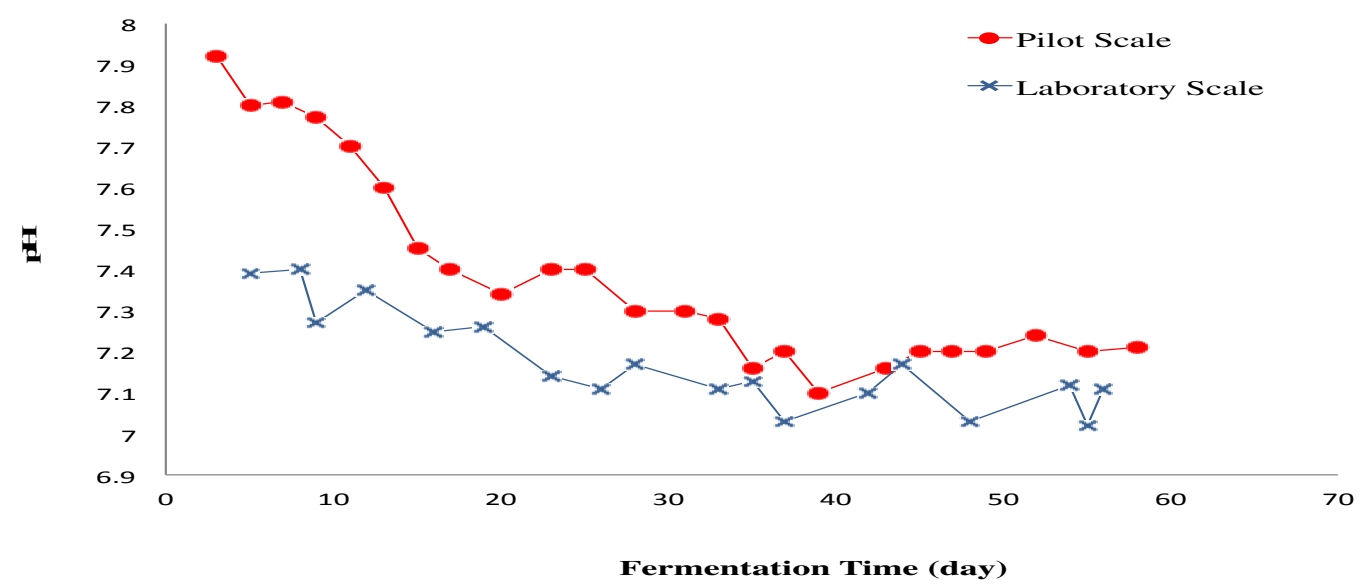

Fig.-5: pH Profiles

Total Solids and Volatile Solids in Digester

Total solid (TS) is the amount of inorganic and organic solids contained in the waste, while volatile solid (VS) is the amount of organic material converted into biogas in waste. TS and VS contents in this experiment were measured according to standards method for the examination of water and wastewater by American Public Health Association (APHA) ${ }^{19,20}$. Fig.-6 and 7 show the TS and VS profiles of the digesters for all the experiments, whether at laboratory scale or pilot scale. For fermentation of POME at laboratory scale, TS and VS content for digester were higher and more stable than at pilot scale. This related to the scale of the experiment, where setting the operating conditions were more difficult to be performed on a larger experimental scale.

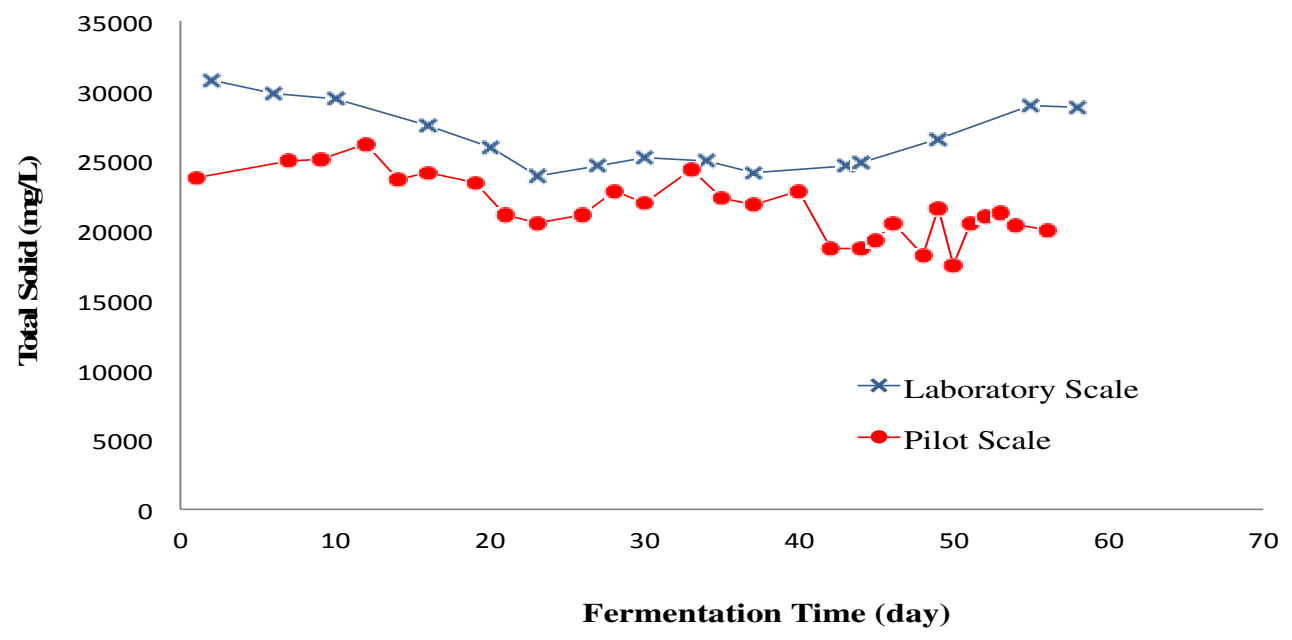

Fig.-6: Total Solid Profile

383

PRODUCTION OF BIOGAS FROM PALM OIL MILL EFFLUENT 
RASĀYAN J. Chem.

Vol. 11 | No. 1 | 378 - 385 | January - March | 2018

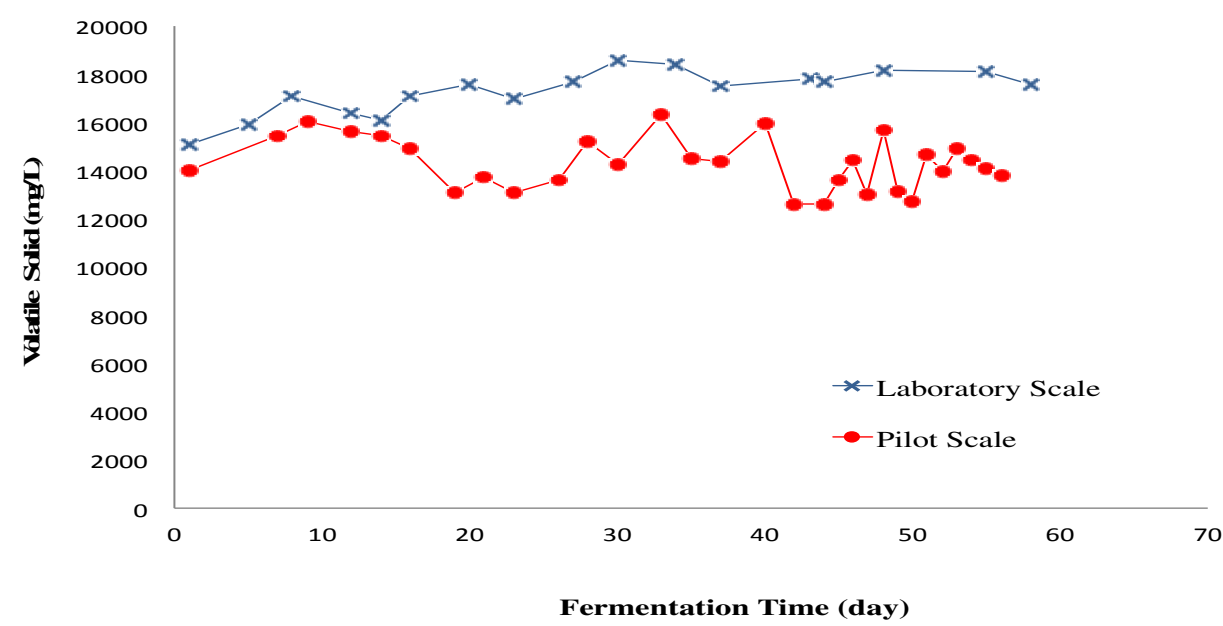

VS Degradation Rate

Fig.-7: Volatile Solid Profile

The rate of VS degradation during the anaerobic fermentation process at laboratory scale needs to be compared with the process at pilot scale to see the change of degradation rate of VS. The rate of VS degradation in POME fermentation process at laboratory scale and pilot scale is shown in Fig.-8.

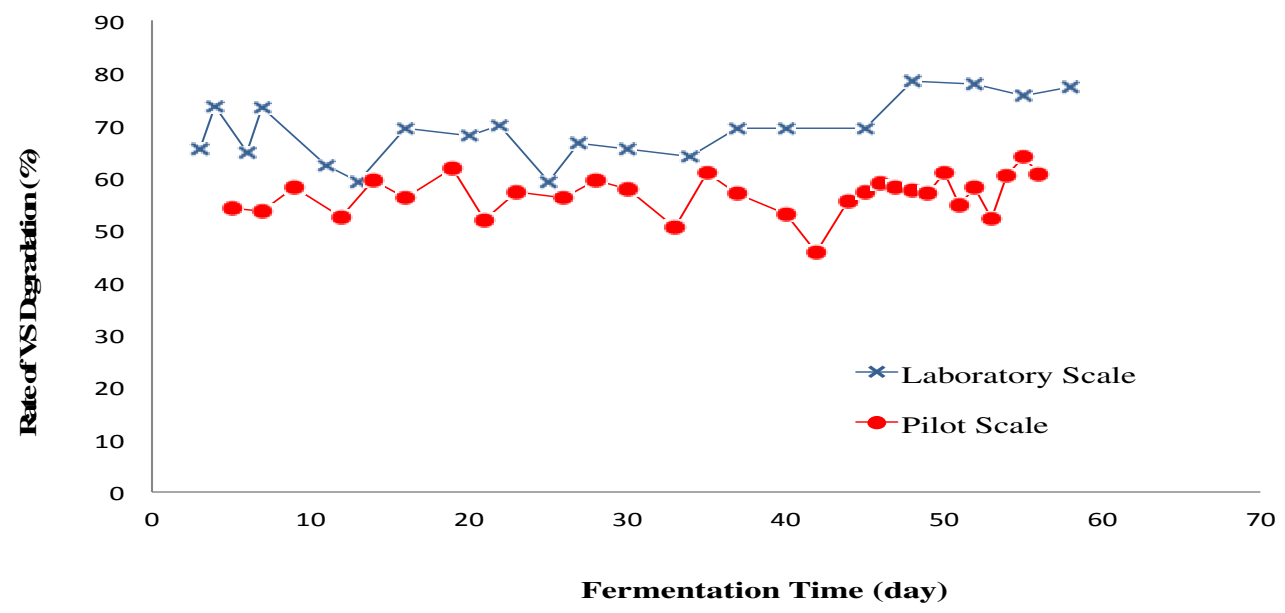

Fig.-8: VS degradation rate

As shown clearly in Fig.-8, for POME fermentation at laboratory scale, the rate of VS degradation is greater than the degradation rate of VS at pilot scale. Where the rate of VS degradation at laboratory scale in the range of 60 to $78 \%$, while at pilot scale in the range of 45 to $65 \%$. Based on the previous discussions, the same reasons are also addressed to this occurrence, why the rate of VS at laboratory scale is greater than at pilot plant. Running a larger system is more complicated than running a smaller system, due to more things that should be controlled.

\section{CONCLUSION}

From the results shown in the discussion section, the performance of the fermentation process at the pilot scale is lower than the pilot scale. This is reasonable because the greater the capacity of the used digester 
will be more difficult to regulate. There are some important things to consider when going to scale up from laboratory scale to pilot scale that is size change, controlling and scaling factors.

\section{ACKNOWLEDGEMENT}

The authors gratefully acknowledge the support from Metawater Co. Ltd - Japan.

\section{REFERENCES}

1. T.C. Koliopoulos, Rasayan J. Chem., 1(3), 437(2008).

2. M.K. Reddy, Y.A. Maruthi, K.A. Lakshmi, Rasayan J. Chem., 3(3), 438(2010).

3. Directorate General Estate Crop, Agricultural Statistics Database, Jakarta: Ministry of Agriculture (2016).

4. J.C. Igwee, C.C. Onyegbado, Global J. Environ. Res., 1(2), 54(2007).

5. L.S. King, L.C. Yu, Eur. Int. J. Sci. Tech., 2, 106(2013).

6. Y.V. Paramitadevi, Rahmatullah, IOP Conf. Ser.: Earth Environ. Sci., 65 ,012048 (2017).

7. F.R. Schmidt, App. Micro. Biotech., 68(4), 425(2005).

8. S. Yacob, M.A. Hassan, Y. Shirai, M. Wakisaka, S. Subash, Chemosphere, 59 ,1575(2005).

9. Irvan, B. Trisakti, H. Daimon, Y. Tomiuchi, Y. Mori, K. Sasaki, 2010, In Proceeding of The 44th Annual Conference of Japan Society on Water Environment, Fukuoka, Japan (2010).

10. M. Faisal, A. Gani, F. Mulana, H. Daimon, Rasayan J. Chem., 9(2),133(2016).

11. Irvan, B. Trisakti, F. Sosanty, Y. Tomiuchi, Asian J. Chem., 28 ,377(2016).

12. S.M. Tauseef, T. Abbasi and S.A. Abbasi, Renew. and Sustain. Energ. Rev., 19, 704(2013).

13. R.M. Clark and R.E. Speece, In Proceedings of the $5^{\text {th }}$ International Conference on Water Pollution Research, pp 27/1-27/14 (1971).

14. J. Cheng, X. Zhu, J. Ni and A. Borthwick, Bioresource Technol., 101, 2729(2010).

15. A.A.L. Zinatizadeh, M. Pirsaheb, H. Bonakdari and H. Younesi, Waste Manage., 30,1798 (2010).

16. P.E. Poh and M.F. Chong, Chem. Eng. Trans., 21, 811(2010).

17. G.D. Najafpour, A.A.L. Zinatizadeh, A.R. Mohamed, M.H. Isa and H. Nasrollahzadeh, Process Biochem., 41, 370(2006).

18. A.A.L. Zinatizadeh, A.R. Mohamed, G.D. Najafpour, M.H. Isa, and H. Nasrollahzadeh, Process Biochem., 41, 1038(2006).

19. A.S. Heerah, A. Mudhoo, R. Mohee, S.K. Sharma, Rasayan J. Chem., 1(3), 503(2008).

20. APHA, Standard methods for the examination of water and wastewater, 20th ed. Washington (DC, USA): American Public Health Association, (1998).

[RJC-2028/2017] 